Review

\title{
The emerging value of P-selectin as a disease marker
}

\author{
János Kappelmayer ${ }^{1, *}$, Béla Nagy Jr${ }^{1}$, Kornél \\ Miszti-Blasius ${ }^{1}$, Zsuzsa Hevessy ${ }^{1}$ and Hendra \\ Setiadi $^{2}$ \\ ${ }^{1}$ Department of Clinical Biochemistry and Molecular \\ Pathology, Medical and Health Science Center, \\ University of Debrecen, Debrecen, Hungary \\ ${ }^{2}$ Cardiovascular Biology Research Program, \\ Oklahoma Medical Research Foundation, Oklahoma \\ City, OK, USA
}

\begin{abstract}
Activated platelets are key components in many arterial disorders. P-selectin is an activation-dependent platelet receptor, which is also identified in endothelial cells. Together with E- and L-selectin it constitutes the selectin family. These transmembrane proteins have continued to attract great interest as they support rapid and reversible cell adhesion in flow systems and thus play an essential role in multicellular interactions during thrombosis and inflammation. Similarly to other lectins, selectins bind to different glycoconjugates with varying affinities. Protein ligands, equipped with the appropriate carbohydrate and sulfate moieties for P-selectin binding, have been identified in normal peripheral blood leukocytes and several non-hematopoietic organs, as well as on cancer cells. For diagnostic purposes, P-selectin can readily be detected on the platelet surface by flow cytometry and by ELISA as a soluble ligand in the plasma. Along with other markers, these data can be used in the assessment of platelet activation status. Such results bear clinical significance since P-selectin has been implicated in the pathogenesis of widespread disorders including coronary artery disease, stroke, diabetes and malignancy.
\end{abstract}

Keywords: microparticle; platelet; P-selectin; P-selectin glycoprotein ligand-1 (PSGL-1); vascular disorders.

\section{Brief historical background}

The year 2004 marks the 20th anniversary of the discovery of P-selectin (Granule Membrane Protein-140, GMP-140; CD62). In 1984, a monoclonal antibody (S12) was described that bound only to activated

\footnotetext{
*Corresponding author: János Kappelmayer, MD, PhD, Department of Clinical Biochemistry and Molecular Pathology, Medical and Health Science Center, University of Debrecen, Nagyerdei krt 98, Debrecen, Hungary Phone: +36-52-431-956, Fax: +36-52-417-631, E-mail: kappelmayer@jaguar.dote.hu
}

platelets and the expression of this protein paralleled with serotonin release (1). Simultaneously, another group also identified a platelet receptor with the antibody KC4 in thrombin-activated platelets that they called platelet activation-dependent external granule membrane (PADGEM) protein (2). Later it became evident that the two groups had identified the same protein. It is a $140 \mathrm{kDa}$ transmembrane glycoprotein that was subsequently designated as GMP-140 (3) and most of its mass is located on the extra-cytoplasmic face of the membrane (4). In the same year, it was demonstrated that GMP-140 was located in the Weibel-Palade bodies of vascular endothelial cells as well $(5,6)$. P-selectin belongs to the selectin family (P-, Land E-selectins) and constitutes a gene cluster on mouse and human chromosome 1 (7). The biological function of the P-selectin molecule was not evident until it was shown that it mediates the interaction of activated platelets with myeloid cells $(8,9)$. A similar function was also observed for the endothelial Pselectin as well (10). One major question remained open for quite some time. Though both platelet and endothelial P-selectin were found to bind to a leukocyte surface receptor, the ligand was not yet identified. Despite strong evidence for a lectin-like interaction (11), Larsen et al. first thought that the ligand was the lineage-specific CD15 (12). However, in 1992 Moore et al. were the first to identify a specific glycoprotein ligand for P-selectin on myeloid cells (13). This dimeric mucin was later cloned and designated as P-selectin glycoprotein ligand-1 (PSGL-1) (14). Subsequent studies have shown that it also functions as a major ligand for L-selectin and to a lesser extent for E-selectin. The past decade has witnessed a plethora of publications on P-selectin, verifying its role as a pathogenetic factor in different multicellular adhesive interactions. Currently, P-selectin is considered as an important disease marker as it participates in many pathological conditions that range from atherosclerosis and inflammation to various psychiatric disorders.

\section{Structure and function of selectins}

Lectins are carbohydrate-binding proteins that have a fairly logical nomenclature. This family of proteins is divided into several sub-families depending on their requirements for binding: C-type lectins (calcium), S-type lectins (free thiol groups), P-type lectins (mannose-phosphate) I-type lectins (immunoglobulin superfamily). The selectins as a member of the C-type lectins mediate adhesion of platelets and leukocytes to the vascular surface. All selectins consist of a lectin 


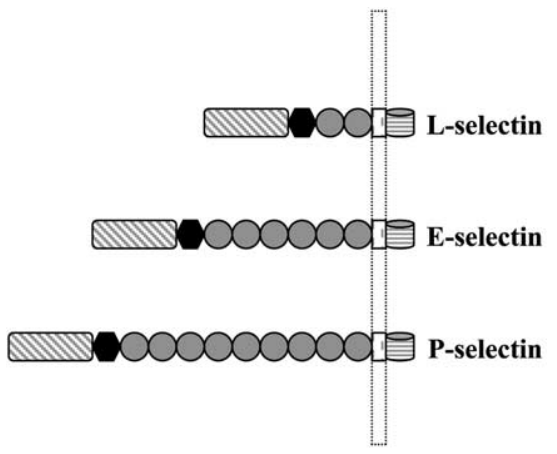

Cytoplasmic domain

(1) Transmembrane domain

Consensus repeat

Figure 1 Domain structure of selectins. The mature selectins share the same structural elements: a short intracytoplasmic domain, a transmembrane domain, a varying number of consensus repeats, an EGF domain and a lectin domain that interacts with glycosulfopeptides.

domain followed by an epidermal growth factor like module, a varying number of short consensus repeats, a transmembrane domain and a short cytoplasmic tail (Figure 1).

L-selectin is constitutively expressed on the leukocyte surface. However, stimulation of bone marrow leukocytes could result in either up- or down-regulation of cell surface expressed L-selectin depending on the agonist (15). E-selectin is expressed only on activated endothelial cells and P-selectin appears on the surface of stimulated platelets and endothelial cells. A recent report also suggests that peritoneal macrophages express P-selectin (16). These selectins can interact with their respective glycoprotein (mucin) ligands on lymph node vessels, endothelium and leukocytes, thus selectins may catalyze multiple cellular interactions. The selectins and their counter receptors are described in Table 1.

All three selectins can bind to PSGL-1, however, appropriate carbohydrate decoration and sulfation of PSGL-1 are necessary for it to reach its optimal capacity to interact with P- and L-selectins $(17,18)$. Data to date suggest that sulfation of PSGL-1 is dispensable for binding to E-selectin $(19,20)$. It appears that the requirement on carbohydrate decoration is also less stringent for the mucin ligands to bind E-selectin. The interaction of human lectins with their counter receptors is rapid and reversible, thus making this bond ideal for mediating rolling adhesion under hydrodynamic stress, like in flowing blood. L-selectin binds to its ligands on high endothelial venules of lymph nodes and on activated endothelial cells at sites of inflammation. E- and P-selectins on activated endothelial cells bind to their respective ligands on leukocytes. P- and L-selectins are primarily responsible for the tethering of flowing leukocytes to the endothelium, but they also support rolling and subsequent leukocyte activation. E-selectin is particularly important for slowing rolling velocities of leukocytes after they have been tethered through $\mathrm{P}$ - or L-selectin. The resultant long transit times are essential for efficient leukocyte adhesion in response to local chemotactic stimuli (21). It mediates the adhesion of blood neutrophils involved in the regulation of inflammatory and immunological events at the interface of the vessel wall and blood (22).

The expression of $\mathrm{P}$ - and E-selectins on the endothelial cells is regulated by different mechanisms. Newly synthesized P-selectin is first transported to Weibel-Palade bodies. Upon stimulation with inflammatory mediators such as histamine and thrombin, these storage granules fuse with the plasma membrane, resulting in rapid redistribution of $\mathrm{P}$-selectin on the cell surface. The appearance of P-selectin on the endothelial cell surface reaches its peak 3-4 minutes following stimulation and then declines to basal level within 30 minutes. Since P-selectin is co-localized with von Willebrand factor (vWF) in the Weibel-Palade bodies, the expression of P-selectin is concomitant with the release of VWF. Complement activation leading to membrane deposition of the C5b-9 proteins causes the release of very high molecular weight vWF multimers, which is accompanied by expression of $\mathrm{P}$-selectin on the endothelial surface (23). More recently it was shown that P-selectin anchors the newly released large vWF multimers to

Table 1 Ligands of various selectins.

\begin{tabular}{|c|c|c|c|}
\hline & Cell type & Protein ligands & Major inducers \\
\hline $\begin{array}{l}\text { P-selectin } \\
\text { (GMP-140, PADGEM, CD62P) }\end{array}$ & $\begin{array}{l}\text { Activated endothelium } \\
\text { and platelets }\end{array}$ & $\begin{array}{l}\text { PSGL-1 } \\
\text { CD24 }\end{array}$ & $\begin{array}{l}\text { Thrombin } \\
\text { Histamine } \\
\text { Complement derivates } \\
\text { Peroxides }\end{array}$ \\
\hline $\begin{array}{l}\text { E-selectin } \\
\text { (ELAM-1, CD62E) }\end{array}$ & Activated endothelium & $\begin{array}{l}\text { PSGL-1 } \\
\text { ESL-1 } \\
\text { L-Selectin }\end{array}$ & $\begin{array}{l}\text { IL-1 } \\
\text { TNF- } \alpha \\
\text { LPS }\end{array}$ \\
\hline $\begin{array}{l}\text { L-selectin } \\
\text { (MEL-14, CD62L) }\end{array}$ & $\begin{array}{l}\text { Memory lymphocytes, } \\
\text { neutrophils, monocytes, } \\
\text { macrophages, eosinophils }\end{array}$ & $\begin{array}{l}\text { PSGL-1 } \\
\text { GlyCAM-1 } \\
\text { MAdCAM-1 } \\
\text { CD34 } \\
\text { Podocalyxin }\end{array}$ & $\begin{array}{l}\text { IL-1 } \\
\text { TNF } \\
\text { IF- } \gamma \\
\text { LPS }\end{array}$ \\
\hline
\end{tabular}

Abbreviations: IL-1, interleukin-1; TNF- $\alpha$, tumor necrosis factor- $\alpha$ LPS, lipopolysaccharide; IF- $\gamma$, interferon- $\gamma$. 
the endothelial surface (24). P-selectin on both the endothelial cell and platelet surface are present in the form of monomers as well as non-covalent dimers (25). Unlike P-selectin, E-selectin is de novo synthesized after appropriate endothelial stimulation, thus it takes at least 4 hours until E-selectin reaches its optimal expression on the endothelial cell surface. The dynamics of their appearance on, and the disappearance from, the cell surface is crucial to mediate cell adhesion. The mechanisms that regulate their cellsurface expression are important to determine their adhesive capacity. It has recently been described that platelet $\mathrm{P}$-selectin expression requires protein kinase $\mathrm{C}$, but not protein tyrosine kinase or phosphoinositide 3-kinase (26). Once expressed on the cell surface, platelet P-selectin remains there until it is shed into the plasma (27), whereas endothelial P-selectin is rapidly internalized in clathrin-coated pits (28). Clustering of P-selectin in clathrin-coated pits enhances its capacity to mediate leukocyte adhesion in flow conditions (29).

\section{Interactions and signaling via PSGL-1}

The best characterized ligand for P-selectin binding is PSGL-1. The binding of P-selectin to PSGL-1 is $\mathrm{Ca}^{2+}$ dependent and is abolished by treatment of the ligand with sialidase. The O-linked glycans are required for $\mathrm{P}$-selectin recognition, whereas the $\mathrm{N}$ linked glycans are not. The ability of PSGL-1 to mediate neutrophil rolling on P-selectin has been demonstrated in both ex vivo and in vivo experiments $(30,31)$. The potency of this molecular interaction to support rolling has been verified as microspheres coated with PSGL-1 roll on P-selectin. However, cellular properties are indispensable to stabilize rolling over a wide range of shear stresses (32).

For the appropriate biochemical responses it is important that the PSGL-1 communicates with intracellular proteins. Indeed the association of the PSGL1 cytoplasmic domain with the actin cytoskeleton is crucial for rolling on P-selectin. Higher doses of an actin cytoskeleton inhibitor dramatically reduce rolling on P-selectin in a dose-dependent fashion. This observation suggests that disruption of the pre-existing actin cytoskeletal network impairs PSGL-1-mediated rolling. PSGL-1 requires interactions between its cytoplasmic domain and the actin cytoskeleton, but not de novo polymerized actin, for leukocyte rolling. PSGL-1 is indirectly linked to the cytoskeletal network via the ERM protein moesin (33). The intracellular signals generated by P-selectin PSGL-1 interaction are largely unknown. The cross-linking of PSGL-1 with an anti-PSGL-1 monoclonal antibody (PL1) or adhesion to $\mathrm{P}$-selectin results in tyrosine phosphorylation. This signaling event does not require co-ligation of Fcy receptors. PL1 increases tyrosine phosphorylation in neutrophils pretreated with cytochalasin B, suggesting that an intact cytoskeleton is not required for this response. This phosphorylation event is important as
PSGL-1 stimulates secretion of IL-8 through a tyrosine phosphorylation dependent pathway (34).

The engagement of neutrophil PSGL- 1 by P-selectin is followed by neutrophil activation including $\beta 2$ integrin activation, which subsequently results in stable cell-cell interaction. This 2-step model of platelet-leukocyte interaction highlights that there is cross-talk between P-selectin and the $\beta 2$ integrin CD11b/18 (35). The subsequent events are the result of the net changes on the leukocyte surface as activation of leukocytes reduces surface PSGL-1 expression and adhesion to P-selectin in vitro (36). Although various inflammatory agents could induce similar densities of $P$-selectin on the endothelial cell surface, their capacity to mediate leukocyte adhesion in flow conditions could be different. This was shown in a recent study, which demonstrated that thrombin-induced activation of RhoA reduces the cell-surface distribution of $\mathrm{P}$ selectin in clathrin-coated pits and thereby the adhesive capacity of P-selectin (37).

\section{The clinical laboratory approach to P-selectin analysis}

It is obvious that for clinical laboratory technicians, the measurement of endothelial P-selectin is mostly not accessible. However, there are still two possible routes for routine analysis: they are platelet $\mathrm{P}$-selectin and soluble P-selectin (sPsel) measurements.

\section{Platelet P-selectin}

Flow cytometry is an advantageous technique for the analysis of platelet receptors. Thus, it is no surprise that the first flow cytometric study of platelet P-selectin was published soon after its discovery (38). In an early paper, Ault et al. described the optimal measuring conditions and the optimization of pre-analytical variables for platelet P-selectin analysis (39). Their whole blood flow cytometric assay of platelet activation using a fixed specimen has been increasingly used in recent years to assess platelet function in clinical research settings. This approach offers several advantages over other clinical tests of platelet function including relative simplicity, minimal manipulation of samples, preventing artifactual in vitro platelet activation, analysis in the physiological milieu of whole blood, high sensitivity for the detection of platelet subpopulations and the need for only minimal blood volumes. A theoretical disadvantage of flow cytometry relates to the possibility that activated platelets may display a decreased survival in circulation, resulting in modest or non-evident platelet activation by flow cytometric analysis $(40,41)$. However, convincing experimental data support that activated platelets continue to circulate. Thus, platelet activation is not necessarily the ultimate stage of platelet life $(42,43)$.

The pre-analytical conditions are extremely important in the analysis of platelet activation markers. Whole blood observation is suitable for the detection of platelet activation status (PAS), avoiding activation 
Table 2 Different sensitivity of direct platelet activation markers.

\begin{tabular}{lcclc}
\hline Thrombin, U/ml & P-selectin, $\%$ & P-selectin MFI & GPIX MFI & Microparticle, $\%$ \\
\hline 0 & 2 & 60 & 182 & 2 \\
0.01 & 8 & 65 & 163 & 2 \\
0.02 & 20 & 69 & 171 & 2 \\
0.03 & 48 & 116 & 109 & 2 \\
0.05 & 66 & 142 & 124 & 3 \\
0.1 & 85 & 168 & 110 & 9 \\
\hline
\end{tabular}

Citrated whole blood sample was stimulated with increasing thrombin concentrations. P-selectin expression, the mean fluorescence intensity (MFI) of P-selectin staining, GPIX fluorescence and the percentage of events in the microparticle gate were registered. P-selectin expression was sensitive to even miniscule amounts of thrombin.

during platelet isolation. In addition, rapid fixation of blood after venipuncture is also important. P-selectin values of platelet-rich plasma (PRP) often result in higher control values compared to whole blood analyses (44). We also found that the preparation of PRP resulted in a random up-regulation of P-selectin. Most authors in different clinical studies found $1-2 \%$ positivity for platelet P-selectin in control subjects by whole blood analysis. Values above this rate mean an enhanced PAS and may predict a hypercoagulable state. More recently the presence of monocyte-platelet aggregates has been shown to be a superior indirect marker of platelet activation in in vitro experiments and in ex vivo samples $(45,46)$. However, compared to other platelet markers at low thrombin concentrations, platelet $\mathrm{P}$-selectin sensitively reflects the status of platelet activation (Table 2). At higher thrombin doses platelets are fragmented, which is easily detectable by scatter analysis (Figure 2). It seems that a method using minimal preparatory steps is the most useful for platelet flow cytometric analysis.

Aside from P-selectin, a panel of tests using other antibodies (e.g., CD63, PAC-1), as well as indirect tests like monocyte-platelet aggregates or monocyte tissue factor expression, can be the most reliable approach for the characterization of activated platelets.

\section{Soluble P-selectin}

In addition to being a platelet membrane receptor, $\mathrm{P}$ selectin can be identified as a circulating plasma protein. In normal plasma, sPsel concentration showed a difference between genders, being higher in males $(47,48)$. It seems that the primary contributors to the formation of sPsel in the physiological state are platelets and thus baseline concentrations are mostly determined by platelet P-selectin shedding. The positive correlation between platelet count and the level of sPsel also supports this conclusion. In patients with bone-marrow aplasia, the sPsel concentration is reduced but is not completely absent. The remaining sPsel in bone marrow aplasia could be derived from a few persisting megakaryocytes and/or platelets or from endothelial cells. Therefore, a minimal release of sPsel from endothelial cells under normal conditions cannot be excluded (49). Verhaar et al. found that progression of vascular, endothelial damage in essential, renovascular and malignant hypertension is associated with a rise in circulating levels of P-selec- tins, which also confirms the link between sPsel and endothelial cells as a source of this protein (50). The shedding mechanism of P-selectin has not been exactly elucidated. The cathepsin G- and neutrophil elastase-mediated PSGL-1 proteolysis may constitute a potential autocrine mechanism for down-regulation of neutrophil adhesion to P-selectin but not for shedding for P-selectin itself (51). Though no direct proofs have been reported, metalloproteinases might be candidates causing P-selectin shedding, as has been found for L-selectin (52). Receptors are also shed from the surface of activated platelets by the generation of microvesicles from the plasma membrane. These microvesicles appear to contain all the major membrane glycoproteins but are depleted in those that have been removed from the platelet membrane by proteolytic cleavage (53). When microparticles (MPs) are isolated from normal human plasma, a large part of the MPs express the platelet marker GPIX and nearly half of the platelet-derived MPs are Pselectin positive (Figure 3 ).

Though MPs express a significant amount of Pselectin it has been shown that the majority of sPsel in plasma is not associated with MPs (54). However, sPsel is not simply a platelet activation marker. In former studies, there was a controversy on whether Pselectin is itself an inducer (55) or rather a supporter of leukocyte responses induced by other agonists (56). Either way, there is a procoagulant state that results from high levels of sPsel in blood (57). The concentration of sPsel is determined by ELISA. In normal subjects, it is mostly found in the $100-200 \mathrm{ng} / \mathrm{ml}$ range. The comparison of sPsel data from different groups in the literature is not always easy. Most of the sPsel values measured by reagents from $R \& D$ System (Abingdon, UK) have values for control subjects in the $20-100 \mathrm{ng} / \mathrm{ml}$ range (58-60), while sPsel values of plasmas from healthy subjects as quantified by the Takara Biomedicals ELISA kit (Takara Shuzo Ltd., Shiga, Japan) are mostly in the range of 150$250 \mathrm{ng} / \mathrm{ml}(61,62)$. These differences may partly be explained by the different antibodies used in the ELISA kits. The Takara assay uses two monoclonal antibodies while the R\&D kit utilizes a monoclonal capture antibody and a peroxidase-conjugated polyclonal antibody for detection. In addition to these methodological variations, differences in blood sampling and sample processing and ethnic background may also account for the observed results. 

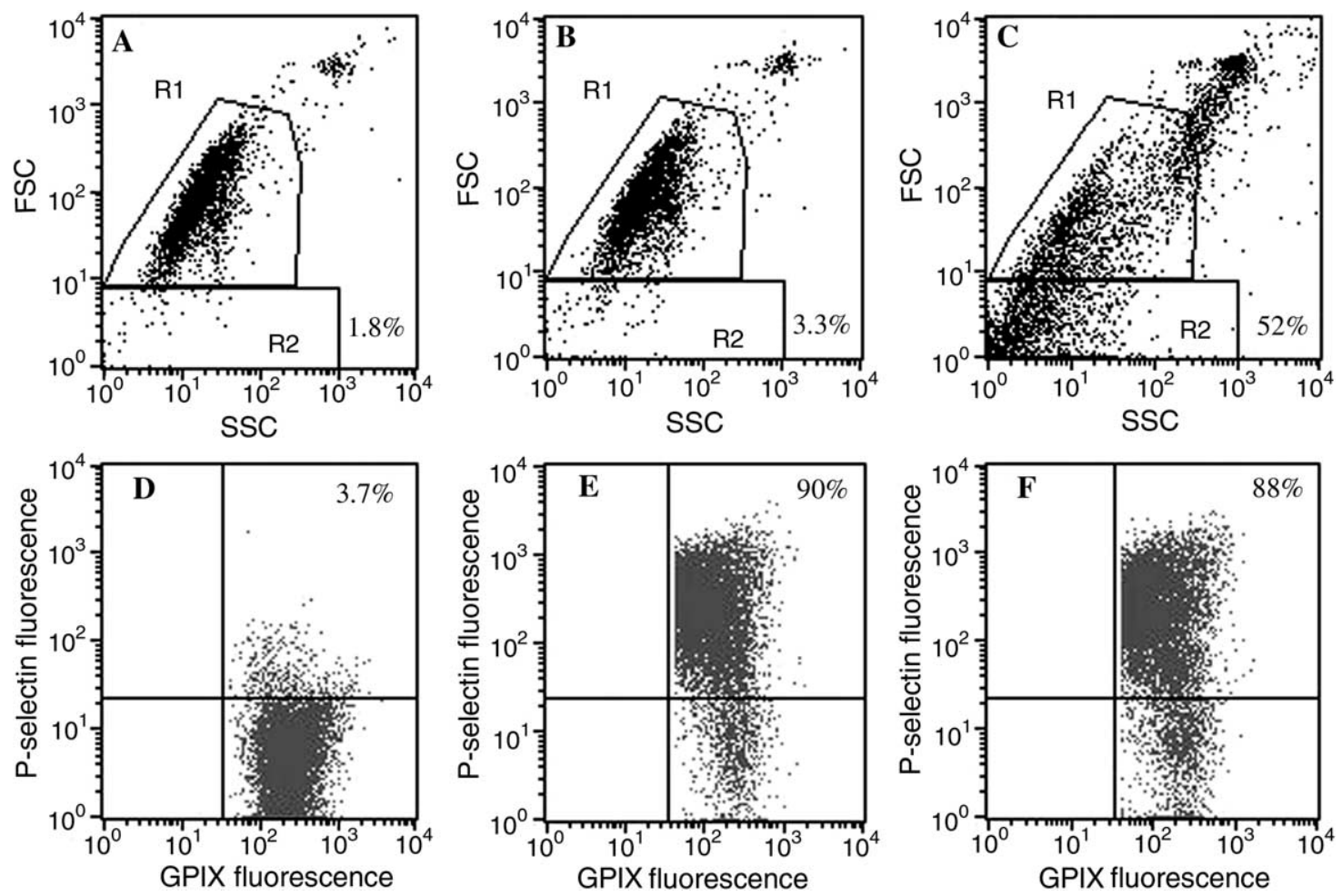

Figure 2 Scatterplots and P-selectin expression in unstimulated and thrombin-stimulated platelets. Platelets were labeled with FITC-conjugated anti-GPIX and PE-conjugated CD62 antibody in unstimulated platelets (panels A, D) and in samples stimulated by $0.05 \mathrm{U} / \mathrm{ml}$ thrombin (panels $\mathrm{B}, \mathrm{E}$ ) and by $0.5 \mathrm{U} / \mathrm{ml}$ thrombin (panels $\mathrm{C}, \mathrm{F}$ ) in the presence of RGDS peptide. In scattergrams the R1 regions depict the platelet gate while R2 depicts the microparticle gate. In the fluorescence plots the Pselectin-positive platelets are described in the upper right quadrant. P-selectin expression reaches maximal value already at a low thrombin dose while a significant increase of the event count in the microvesicle gate is only evident at a high thrombin dose.

\section{P-selectin: a disease marker}

\section{Thrombosis and cardiac diseases}

The initial steps of atherosclerosis are associated with endothelial cell dysfunction, the development of their prothrombotic activity and with increased adhesiveness for platelets and leukocytes. Different interactions between platelets and endothelial cells through $P$-selectin binding generate signals to recruit inflammatory cells to the site of vascular injury and promote the extravasation of leukocytes to the inner layers of the vessel wall. Platelets that accumulate at the site of arterial injury can also more directly recruit monocytes to the vessel wall through PSGL-1-P-selectin interaction. Monocyte-platelet aggregates have been identified in the peripheral blood of patients with coronary artery disease and may serve as markers of disease activity $(63,64)$. In thrombotic consumptive disorders sPsel levels were found to be elevated by several authors $(65,66)$.

$\mathrm{P}$-selectin as an adhesion molecule plays an important role in atherosclerosis (67). In the P-selectin-deficient mice a number of defects in leukocyte adhesion are observed, notably: total absence of leukocyte rolling and delayed recruitment of neutrophils, thus demonstrating the important role of P-selectin in these processes (68). Furthermore, P-selectin-deficient mice on an atherogenic diet formed significantly smaller fatty streaks in aorta than did P-selectin-positive mice
(69). Similarly to the studies in P-selectin knockout animals, in vivo studies using P-selectin blocking antibodies proved to be very conclusive. In animal studies, administration of monoclonal antibodies (PB1.3, NBP1.6) against $P$-selectin resulted in infarct size reduction. They significantly decreased adherence of non-stimulated polymorphonuclear leukocytes (PMNs) to thrombin and histamine-stimulated endothelial cells, exerting significant endothelial preservation and cardioprotection in myocardial ischemia (70). Furthermore, P-selectin blocking accelerated pharmacological thrombolysis in a primate model of arterial thrombosis (71).

In another approach (72) it was found that in the atherosclerosis prone apolipoprotein $\mathrm{E}$ (apoE)-deficient mouse model, P-selectin facilitated atherosclerotic lesion development. In states of extracorporeal circulation, platelets were found to be activated (7375) and it is quite possible that the leukocyte activation we previously observed in such states $(76,77)$ is associated with prior platelet activation. P-selectin expression correlates well with early and advanced lesion development, so it has become a candidate target for anti-atherogenic strategies and its ligands can be considered as promising tools to target or antagonize P-selectin function within the chronically inflamed arterial wall (78). Platelets adhere to damaged endothelial cells and collagen while becoming activated, causing inflammation by releasing the con- 

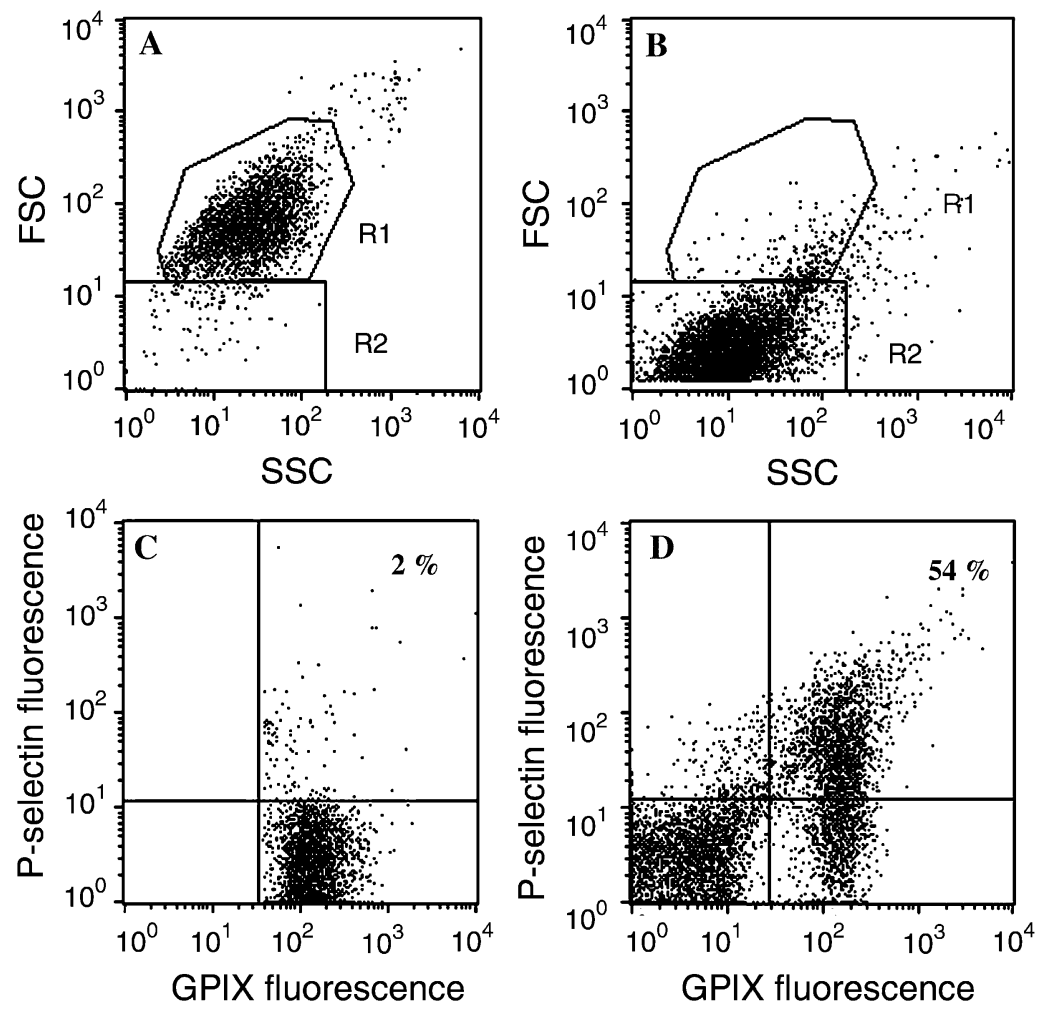

Figure 3 P-selectin expression is different in intact platelets and microparticles. In unstimulated whole blood, platelet $\mathrm{P}$ selectin is only $2 \%$ (panels $A, C$ ). The majority of the microparticles separated from the same sample are of platelet origin (GPIX positive) and $54 \%$ of them express P-selectin (panels B, D).

tents of their granules in peripheral vessels. In patients with peripheral arterial disease, platelets are hyperactivated and circulate in an activated state (79, $80)$. A recent review summarizes the importance of $\mathrm{P}$-selectin in cardiovascular disease (81).

\section{Venous thrombosis}

In addition to the role of P-selectin in arterial thrombosis, it could also be responsible for enhanced platelet activation in deep venous thrombosis (DVT). sPsel was found to be increased in patients with DVT and may be a reflection of a generalized hypercoagulable state of platelets when thrombus was present $(82,83)$. This hypothesis has been confirmed by studies on inhibiting P-selectin by a selectin antagonist, the recombinant PSGL-1 immunoglobulin that decreased inflammation and limited venous thrombosis $(84,85)$. Elevated levels of P-selectin can amplify thrombosis mediated by procoagulant MPs. E- and P-selectin gene-interrupted mice (EPKO) had the smallest thrombi compared to wild-type animals and mice with high circulating levels of sPsel (CT). A significant difference was noted between the CT and EPKO groups for neutrophils, monocytes and total inflammatory cells (86). It was observed that mice lacking PSGL-1 or P-selectin, or wild-type mice infused with blocking P-selectin antibodies, developed thrombi with minimal tissue factor and fibrin. They indicated that one pathway for the inhibition of blood coagulation in vivo involves the accumulation of tissue fac- tor- and PSGL-1-containing MPs in the platelet thrombus expressing P-selectin (87).

\section{Stroke}

The increased risk of stroke may be related to the prothrombotic or hypercoagulable state with abnormalities of hemostasis including platelet activation. The participation of activated platelets in the development of focal ischemia was already suspected in the 1960s. Marquardt et al. determined the rate of healthy control subjects below $2 \%$ P-selectin positivity and they found a 2- to 2.5-fold increase in CD62 positivity in patients at the first day after cerebral ischemia. The P-selectin level then decreased gradually from the second day and reached the normal rate 90 days after stroke. No correlation was found between inflammatory markers (fibrinogen, leukocyte count, C-reactive protein) and the degree of platelet activation (88). A relatively high level of platelet $P$ selectin expression was observed in cardioembolic stroke (CES) by Yamazaki et al. Two to four percent of P-selectin expressed platelets were measured in CES patients compared to the $1-1.5 \%$ observed in healthy controls (89). In other studies, the increased expression of P-selectin on platelets $(7.6 \pm 0.9 \%$ vs. $4.8 \pm 0.7 \%)$ was associated with reduced NO levels and was a risk factor for silent cerebral infarction (90). Mean blood concentration of $P$-selectin within 7 days of stroke onset was significantly higher compared to controls (91). Ischemic stroke is a multicausal disorder that results in enhanced thrombin generation, and the 
Table 3 The increase in platelet and soluble P-selectin in different vascular disorders.

\begin{tabular}{|c|c|c|c|c|c|}
\hline \multirow[t]{2}{*}{ References } & \multirow{2}{*}{$\begin{array}{l}\text { Type of } \\
\text { vascular } \\
\text { disorder }\end{array}$} & \multirow{2}{*}{$\begin{array}{l}\text { Number } \\
\text { of } \\
\text { patients }\end{array}$} & \multirow{2}{*}{$\begin{array}{l}\text { Number } \\
\text { of } \\
\text { controls }\end{array}$} & \multicolumn{2}{|c|}{ P-selectin ratio } \\
\hline & & & & Platelet & Soluble \\
\hline Blann AD et al. Blood Coagul Fibrinolysis 1996 (62) & PVD & 170 & 119 & & 1.5 \\
\hline Furman MI et al. J Am Coll Cardiol 1998 (63) & CAD & 19 & 19 & 1.4 & \\
\hline Gurbel PA et al. Am J Cardiol 2001 (60) & Myocardial infarction & 23 & 10 & 1.4 & 2.6 \\
\hline Ikeda $\mathrm{H}$ et al. Circulation 1995 (61) & Unstable angina & 23 & 15 & & 2 \\
\hline Jilma B et al. Thromb Haemost 1996 (96) & Type 1 diabetes & 42 & 42 & & 1.2 \\
\hline Kopp HP et al. Exp Clin Endocrinol Diabetes 1998 (97) & Type 1 diabetes & 18 & 18 & & 1.9 \\
\hline Marquardt L et al. Stroke 2002 (88) & Ischemic stroke & 50 & 30 & 2 & \\
\hline Minamino T et al. Circulation 1998 (90) & Atrial fibrillation & 25 & 25 & 1.6 & \\
\hline Tschoepe D et al. Diabetes 1995 (95) & Type 1 diabetes & 21 & 50 & 5 & \\
\hline Tschoepe D et al. Diabetologia 1997 (98) & Type 1 diabetes & 19 & 50 & 3.2 & \\
\hline Yamazaki M et al. Thromb Res 2001 (89) & Cerebral infarction & 254 & 30 & 3 & \\
\hline Zeiger F et al. Blood Coagul Fibrinolysis 2000 (99) & PVD & 50 & 50 & 1.4 & \\
\hline
\end{tabular}

Total: 714

458 Mean: 2.4

1.8

P-selectin values were expressed as patient/control ratio for both platelet and soluble P-selectin. PVD, peripheral vascular disease.

observed cellular changes may be interrelated. In previous studies we observed elevation in the monocyte tissue factor antigen and activity in early days after ischemic stroke (92). This might be related to platelet activation as platelets have been shown to be involved in the generation of monocyte tissue factor activity (93). These findings indicate the importance of the detection of P-selectin expression in the identification of pre-thrombotic status.

\section{Diabetes}

The majority of the clinical studies investigating platelet or sPsel have been carried out on vascular disorders and with hypercoagulability. All of these studies reported an increase in $\mathrm{P}$-selectin expression (Table 3). Patients with diabetes mellitus (DM) frequently have hypercoagulable blood, as evidenced by increased prothrombotic activity, depressed fibrinolysis, reduced endothelial thromboresistance and platelet hyperreactivity. These alterations lower the coagulation threshold in the arterial circulation. The increased functional properties of diabetic platelets result from the primary release of larger platelets with enhanced thromboxane formation capacity and increased numbers of functional glycoprotein receptors, GPIb and GPIIb/IIla. The megakaryocyte-platelet system is turned on in DM (94). The pathophysiological development of atherothrombotic endpoints in the diabetic environment starts with endothelial dysfunction and is mediated by accelerated atherosclerosis. There is activation of exposed luminal adhesion molecules, resulting in the adherence of white blood cells and/or platelets. These changes favor repeated acute occlusive thrombosis, which ultimately triggers the gross infarct.

Tschoepe et al. reported that even patients with newly diagnosed insulin-dependent diabetes mellitus (IDDM) show clearly increased levels of circulating activated platelets with exposed adhesion molecules.
The CD62 + platelet levels were initially 5 times higher than that of controls (95). Others also found a higher median plasma level of circulating P-selectin in patients with IDDM with increased P-selectin expression on platelets $(96,97)$. Moreover, this activation was not related to the improvement of glycemic control with intensified insulin therapy. Most strikingly, CD62P-positive platelets could also be found in metabolically healthy first-degree relatives of clinically manifested type 1 diabetic patients. The mean number of CD62-positive platelets was increased 3.2-fold in pre-diabetic patients. Thus, intravasal platelet activation is already present in potentially pre-diabetic subjects (98). It is questionable whether hypercoagulability in diabetes, including the hyperactivity of the megakaryocyte-platelet system, can be normalized by strict and effective near-normoglycemia alone (100). Nevertheless it is interesting that even a minor elevation of blood glucose in postprandial hyperglycemia causing platelet hyperactivity can be monitored by direct or indirect platelet activation assays (101, 102).

\section{Malignancy}

One area where the involvement of P-selectin has been shown convincingly, both in experimental and clinical studies, is oncology. The clinical prognosis and metastatic progression of many epithelial carcinomas has been correlated with the production of tumor mucins. Metastasis is thought to involve the formation of tumor-platelet-leukocyte emboli and their interaction with the endothelium of distant organs. P-selectin that normally interacts with PSGL1 can facilitate the metastatic seeding of mucin-producing carcinomas. This has clearly been verified in $P$-selectin-deficient mice that displayed significantly slower growth of subcutaneously implanted human colon carcinoma cells and generated fewer lung metastases from intravenously injected cells (103). In 
several clinical studies CD24, a heavily glycosylated mucin, has been shown to be an independent prognostic marker of survival in ovarian cancer (104) and in non-small cell lung cancer (105). In addition, it has also been shown that heparin treatment attenuates tumor metastasis in mice by inhibiting P-selectinmediated interactions of platelets with carcinoma cellsurface mucin ligands. Human P-selectin is even more sensitive to heparin than mouse $\mathrm{P}$-selectin, giving significant inhibition at concentrations that are in the clinically acceptable range. Heparin can block P-selectin-based platelet interactions with tumor cell-surface mucins and thereby attenuate metastasis. In vivo, Pselectin-mediated tumor cell-platelet interaction is impaired by mucin removal or by heparin treatment (106).

Tumors have other means to enhance invasiveness that are also $\mathrm{P}$-selectin related. In melanomas a reduced $\mathrm{P}$-selectin expression was found in the tumor endothelium. This suggests that a reduced expression of P-selectin may contribute to a protective mechanism in melanoma by preventing infiltration by leukocytes (107). In addition to the role of cell-associated $\mathrm{P}$-selectin, the concentrations of sPsel, fibrinogen and $\mathrm{vWf}$ are raised in patients with hematological and breast cancer. vWf and sPsel are higher in the hematological cancers than in breast cancer patients. The sPsel as a platelet marker is unrelated to the type or stage of breast cancer (58). These data suggest that adhesion molecules may be useful targets for cancer therapy and in cardiovascular disease.

\section{Miscellaneous applications}

Recently, some changes of platelets in patients with depression were demonstrated. The number of GPIb receptors on platelets was enhanced in depressed patients. Surface expression of P-selectin was also significantly increased in these patients as compared to control subjects (108).

A possible emerging area of platelet and sPsel analysis could serve as therapy monitoring tests. The effects of a single dose of aspirin on human platelets can be measured by different flow cytometric methods including determination of $\mathrm{CD} 62 \mathrm{P}+$ platelet percent. After using aspirin therapy, P-selectin expression significantly decreased (109). Klinkhardt et al. found clopidogrel or aspirin combined with clopidogrel therapy more effective for reducing $P$-selectin expression than aspirin treatment alone (64). The success of thrombolytic therapy could also be followed by soluble and platelet P-selectin measurements. After thrombolytic therapy the sPsel level rapidly returned toward baseline at 6 hours, although platelet P-selectin showed only a moderate decrease in patients with successful reperfusion (110). One further application of the whole blood flow cytometric assay of platelet function in PAD patients is the identification of those patients who might benefit from additional antiplatelet therapy, like the ADP-receptor antagonist clopidogrel in the case of very high ADPinduced P-selectin levels on platelets (99).

\section{PSGL-1 in health and disease}

The expression of this dimeric glycoprotein on neutrophils, monocytes and T cells is important to mediate these cells to roll on selectins (111). Later its presence was described in several non-hematopoietic tissues as well (112). The interaction of P-selectin with PSGL-1 is a key element in many of the above listed pathological states. It was not until the PSGL-1 knockout mouse was generated that the role of this molecule became obvious in physiological and pathological states. The PSGL-1 knockout animals show impaired tethering and rolling of myeloid cells on Eselectin. In these knockout animals, the neutrophil count is increased as cells are retained in the circulation for a prolonged time (113). PSGL-1 may be implicated in the adhesive events in leukemic cells, as we have previously demonstrated the presence of a differential expression pattern of PSGL-1 during myeloid hematopoietic development. In addition, the quantification of surface PSGL-1 may help to differentiate myeloblasts from monoblasts by immunophenotyping (114). Though previous studies underline the harmful consequences of the P-selectin-PSGL1 interaction, it is interesting to note that a more recent study has shown the beneficial values of this interaction as it generates MPs that correct the bleeding tendency in a mouse model of coagulopathy (115). This means that the missing factor VIII can be bypassed by providing another source of thrombin generation. In addition, the soluble form of PSGL-1 is now used as an effective P-selectin blocking agent at both functional and molecular levels (116) that ameliorate coronary blood flow in various pathological states.

In addition to being a platelet activation marker as it was described two decades ago, P-selectin can now be regarded as an important pathogenetic factor and a disease marker. Aside from being a useful molecular marker, its interactions can be exploited for therapeutic purposes as well.

\section{Acknowledgements}

The study was supported by grants: OTKA T046863 (to J. Kappelmayer), Mec-13/2002 (to Z. Hevessy) and by a beginning Grant-in-Aid from the Heartland Affiliate of the American Heart Association (to H. Setiadi). The authors are indebted to Anikó Veszprémi Györfi for technical assistance.

\section{References}

1. McEver PR, Martin MN. A monoclonal antibody to a membrane glycoprotein binds to only activated platelets. J Biol Chem 1984;259:9799-804.

2. Hsu-Lin SC, Berman CL, Furie BC, August D, Furie B. A platelet membrane protein expressed during platelet activation and secretion. J Biol Chem 1984;259:9121-6. 
3. Stenberg PE, McEver RP, Shuman MA, Jacques YV, Bainton DF. A platelet alpha-granule membrane protein (GMP-140) is expressed on the plasma membrane after activation. J Cell Biol 1985;101:880-6.

4. Johnston GI, Cook RG, McEver RP. Cloning of GMP/140, a granule membrane protein of platelets and endothelium: sequence similarity to proteins involved in cell adhesion and inflammation. Cell 1989;56:1033-44.

5. McEver RP, Beckstead JM, Moore KL, Marshall-Carlson L, Bainton DF. GMP-140, a platelet alpha-granule membrane protein, is also synthesized by vascular endothelial cells and is localized in Weibel-Palade bodies. J Clin Invest 1989;84:92-9.

6. Bonfanti $R$, Furie BC, Furie $B$, Wagner DD. PADGEM (GMP-140) is a component of Weibel-Palade bodies of human endothelial cells. Blood 1989;73:1109-12.

7. Watson ML, Kingsmore SF, Johnston GI, Siegelman MH, Le Beau MM, Lemons RS, et al. Genomic organization of the selectin family of leukocyte adhesion molecules on human and mouse chromosome 1. J Exp Med 1990;172:263-72.

8. Larsen E, Celi A, Gilbert GE, Furie BC, Erban JK, Bonfanti $\mathrm{R}$, et al. PADGEM protein: a receptor that mediates the interaction of activated platelets with neutrophils and monocytes. Cell 1989;59:305-12.

9. Hamburger SA, McEver RP. GMP-140 mediates adhesion of stimulated platelets to neutrophils. Blood 1990;75:550-4.

10. Geng JG, Bevilacqua MP, Moore KL, Mclntyre TM, Prescott SM, Kim JM, et al. Rapid neutrophil adhesion to activated endothelium mediated by GMP-140. Nature 1990;343:757-60.

11. Moore KL, Varki A, McEver RP. GMP-140 binds to a glycoprotein receptor on human neutrophils: evidence for a lectin-like interaction. J Cell Biol 1991;112:491-9.

12. Larsen E, Palabrica T, Sajer S, Gilbert GE, Wagner DD, Furie BC, et al. PADGEM-dependent adhesion of platelets to monocytes and neutrophils is mediated by a lineage-specific carbohydrate, LNF III (CD15). Cell 1990;63:467-74.

13. Moore KL, Stults NL, Diaz S, Smith DF, Cummings RD, Varki $A$, et al. Identification of a specific glycoprotein ligand-1 for P-selectin (CD62) on myeloid cells. J Biol Chem 1992;118:445-6.

14. Sako D, Chang XJ, Barone KM, Vachino G, White HM, Shaw G, et al. Expression cloning of a functional glycoprotein ligand for P-selectin. Cell 1993;75:1179-86.

15. Salmi M, Jalkanen S. Regulation of L-selectin expression on cultured bone marrow leukocytes and their precursors. Eur J Immunol 1992;22:835-43.

16. Tchenychev B, Furie B, Furie BC. Peritoneal macrophages express both P-selectin and PSGL-1. J Cell Biol 2003;163:1145-55.

17. Li F, Wilkins PP, Crawley S, Weinstein J, Cummings RD, McEver RP. Post-translational modifications of recombinant $P$-selectin glycoprotein ligand-1 required for binding to P- and E-selectin. J Biol Chem 1996;271:3255-64.

18. Ramachandran W, Nollert MU, Qiu H, Liu WJ, Cummings RD, Zhu C, et al. Tyrosine replacement in P-selectin glycoprotein ligand-1 affects distinct kinetic and mechanical properties of bonds with P- and L-selectin. Proc Natl Acad Sci USA 1999;96:13 771-6.

19. Khan Al, Landis RC, Malhotra R. L-selectin ligands in lymphoid tissues and models of inflammation. Inflammation 2003;27:265-80.

20. Vestweber D, Blanks JE. Mechanisms that regulate the function of the selectins and their ligands. Physiol Rev 1999;79:181-213.

21. Ley K, Allietta M, Bullard DC, Morgan S. Importance of E-selectin for firm leukocyte adhesion in vivo. Circ Res 1998;83:287-94.
22. Bevilacqua MP, Stengelin S, Gimbrone MA Jr, Seed B. Endothelial leukocyte adhesion molecules 1: an inducible receptor for neutrophils related to complement regulatory proteins and lectins. Science 1989;243:1160-5.

23. Hattori R, Hamilton KK, McEver RP, Sims PJ. Complement proteins $\mathrm{C} 5 \mathrm{~b}-9$ induce secretion of high molecular weight multimers of endothelial von Willebrand factor and translocation of granule membrane protein GMP140 to the cell surface. J Biol Chem 1989;264:9053-60.

24. Padilla A, Moake JL, Bernardo A, Ball C, Wang Y, Arya $M$, et al. P-selectin anchors newly released ultra-large von Willebrand factor multimers to the endothelial cell surface. Blood 2004;103:2150-6.

25. Barkalow FJ, Barkalow KL, Mayadas TN. Dimerization of P-selectin in platelets and endothelial cells. Blood 2000,96:3070-7.

26. Libersan D, Merhi Y. Platelet P-selectin expression: requirement for protein kinase $\mathrm{C}$, but not protein tyrosine kinase or phosphoinositide 3-kinase. Thromb Haemost 2003;89:1016-23.

27. Michelson AD, Barnard MR, Hechtman HB, MacGregor $\mathrm{H}$, Connolly RJ, Loscalzo J, et al. In vivo tracking of platelets: circulating degranulated platelets rapidly lose surface P-selectin but continue to circulate and function. Proc Natl Acad Sci 1996;93:11 877-82.

28. Setiadi H, Disdier M, Green SA, Canfield WM, McEver RP. Residues throughout the cytoplasmic domain affect the internalization efficiency of P-selectin. J Biol Chem 1995:270:26 818-26.

29. Setiadi H, Sedgewick G, Erlandsen SL, McEver RP. Interactions of the cytoplasmatic domain of P-selectin with clathrin-coated pits enhances leukocyte adhesion under flow. J Cell Biol 1998;142:859-71.

30. Moore KL, Patel KD, Bruehl RE, Fugang L, Johnson DA, Lichenstein HS, et al. P-selectin glycoprotein ligand-1 mediates rolling of human neutrophils on P-selectin. $J$ Biol Chem 1995;128:661-71.

31. Norman KE, Katopodis AG, Thoma G, Kolbinger F, Hicks $\mathrm{AE}$, Cotter MJ, et al. P-selectin glycoprotein ligand-1 supports rolling on $\mathrm{E}$ - and P-selectin in vivo. Blood 2000;96:3585-91.

32. Yago T, Leppanen A, Qiu H, Marcus WD, Nollert MU, Zhu C, et al. Distinct molecular and cellular contributions to stabilizing selectin-mediated rolling under flow. J Cell Biol 2002;158:787-99.

33. Snapp KR, Heitzig CE, Kansas GS. Attachment of the PSGL-1 cytoplasmic domain to the actin cytoskeleton is essential for leukocyte rolling on P-selectin. Blood 2002;99:4494-502.

34. Hidari KI, Weyrich AS, Zimmerman GA, McEver RP. Engagement of P-selectin glycoprotein ligand-1 enhances tyrosine phosphorylation and activates mitogen-activated protein kinases in human neutrophils. J Biol Chem 1997; 272:28 750-56.

35. Evangelista V, Manarini S, Rotondo S, Martelli N, Polischuk R, McGregor JL et al. Platelet/polymorphonuclear leukocyte interaction in dynamic conditions: evidence of adhesion cascade and cross talk between P-selectin and the $\beta 2$ integrin CD11b/CD18. Blood 1996;88:4183-94.

36. Davenpeck KL, Brummet ME, Hudson SA, Mayer RJ, Bochner BS. Activation of human leukocytes reduces surface P-selectin glycoprotein ligand-1 (PSGL-1, CD162) and adhesion to P-selectin in vitro. Immunology 2000;165:2764-72

37. Setiadi H, McEver RP. Signal-dependent distribution of cell surface $P$-selectin in clathrin-coated pits affects leukocyte rolling under flow. J Cell Biol 2003;163:1385-95.

38. Johnston GI, Pickett EB, McEver RP, George JN. Heterogeneity of platelet secretion in response to thrombin demonstrated by flow cytometry. Blood 1987;69:1401-3.

39. Ault KA, Rinder HM, Mitchell JG, Rinder CS, Lambrew CT, Hillman RS. Correlated measurement of platelet 
release and aggregation in whole blood. Cytometry 1989;10:448-55.

40. Rinder HM, Murphy M, Mitchell JG, Stocks J, Ault KA, Hillman RS. Progressive platelet activation with storage: evidence for shortened survival of activated platelets after transfusion. Transfusion 1991;31:409-14.

41. Sirolli V, Ballone E, Garofalo D, Merciaro G, Settefrati N, Di Mascio R, et al. Platelet activation markers in patients with nephrotic syndrome. A comparative study of different platelet function tests. Nephron 2002;91:424-30.

42. Berger G, Hartwell DW, Wagner DD. P-selectin and platelet clearance. Blood 1998;92:4446-52.

43. Michelson AD, Bernard MR, Hechtman HB, MacGragor $\mathrm{H}$, Connolly RJ, Loscalzol J, et al. In vivo tracking of platelets: circulating degranulated platelets rapidly lose surface P-selectin but continue to circulate and function. Proc Natl Acad Sci USA 1996;93:11 877-82.

44. Weikert U, KühI U, Schultheiss HP, Rauch U. Platelet activation is increased in patients with cardiomyopathy: myocardial inflammation and platelet reactivity. Platelets 2002;13:487-91.

45. Michelson AD, Barnard MR, Krueger LA, Valeri CR, Furman MI. Circulating monocyte-platelet aggregates are a more sensitive marker of in vivo platelet activation than platelet surface P-selectin. Circulation 2001;104:1533-7.

46. Káplár M, Kappelmayer J, Kiss A, Szabó K, Udvardy M. Increased leukocyte-platelet adhesion in chronic myeloproliferative disorders with high platelet counts. Platelet 2000;11:183-4.

47. Dunlop LC, Skinner MP, Bendall LJ, Favaloro EJ, Castaldi PA, Gorman JJ, et al. Characterization of GMP-140 (Pselectin) as a circulating plasma protein. J Exp Med 1992;175:1147-50.

48. Conway DS, Pearce LA, Chin BS, Hart RG, Lip GY. Plasma von Willebrand factor and sPsel as indices of endothelial damage and platelet activation in 1321 patients with nonvalvular atrial fibrillation: relationship to stroke risk factors. Circulation 2002;106:1962-7.

49. Fijnheer R, Frijns JM, Korteweg J, Rommes H, Peters JH, Sixma JJ, et al. The origin of P-selectin as a circulating plasma protein. Thromb Haemost 1997;77:1081-5.

50. Verhaar MC, Beutler JJ, Giallard CA, Koomans HA, Fijnheer R, Rabelink TJ. Progressive vascular damage in hypertension is associated with increased levels of circulating P-selectin. J Hypertens 1998;16:45-50.

51. Gardiner EE, De Luca M, McNally T, Michelson AD, Andrews RK, Berndt MC. Regulation of P-selectin binding to the neutrophil P-selectin counter-receptor P-selectin glycoprotein ligand-1 by neutrophil elastase and cathepsin G. Blood 2001;98:1440-7.

52. Walcheck B, Kahn J, Fisher JM, Wang BB, Fisk RS, Payan $\mathrm{DG}$, et al. Neutrophils rolling altered by inhibition of $\mathrm{L}$ selectin shedding in vitro. Nature 1996;380:720-3.

53. Fox JE. Shedding of adhesion receptors from the surface of the activated platelets. Blood Coagul Fibrinolysis 1994;5:291-304.

54. Osmanovic N, Romijn FP, Joop K, Sturk A, Nieuwland R. Soluble selectins in sepsis: microparticles-associated, but only to a minor degree. Thromb Haemost 2000;84:731-2.

55. Celi A, Pellegrini G, Lorenzet R, De Blasi A, Ready N, Furie $B C$, et al. P-selectin induces the expression of tissue factor on monocytes. Proc Natl Acad Sci USA 1994;91:8767-71.

56. Lorant DE, Topham MK, Whatley RE, McEver RP, McIntyre, Prescott SM, et al. Inflammatory roles of P-selectin. J Clin Invest 1993;92:559-70.

57. André P, Hartwell D, Hrachovinová I, Saffaripour S, Wagner DD. Pro-coagulant state resulting from high levels of sPsel in blood. Proc Natl Acad Sci 2000;97:13 835-40.

58. Blann AD, Gurney D, Wadley M, Bareford D, Stonelake $\mathrm{P}$, Lip GYH. Increased soluble P-selectin in patients with haematological and breast cancer: a comparison with fibrinogen, plasminogen activator inhibitor and von Willebrand factor. Blood Coagul Fibrinolysis 2001;12:43-50.

59. Ridker PM, Buring JE, Rifai N. Soluble P-selectin and the risk of future cardiovascular events. Circulation 2001;103:491-5.

60. Gurbel PA, O'Connor CM, Dalesandro MR, Serebruany $\mathrm{VL}$. Relation of soluble and platelet P-selectin to early outcome in patients with acute myocardial infarction after thrombolytic therapy. Am J Cardiol 2001;87:774-7.

61. Ikeda H, Takajo Y, Ichiki K, Ueno T, Maki S, Noda T, et al. Increased soluble form of P-selectin in patients with unstable angina. Circulation 1995;92:1693-6.

62. Blann AD, Seigneur M, Boisseau MR, Taberner DA, McCollum CN. Soluble P-selectin in peripheral vascular disease: relationship to the location and extent of atherosclerotic disease and its risk factors. Blood Coagul Fibrinolysis 1996;7:789-93.

63. Furman MI, Beniot SE, Barnard MR, Valeri CR, Borbone $\mathrm{ML}$, Becker RC, et al. Increased platelet reactivity and circulating monocyte-platelet aggregates in patients with stable coronary artery disease. J Am Coll Cardiol 1998;31:352-8.

64. Klinkhardt U, Bauersachs R, Adams J, Graff J, LindhoffLast E, Harder S. Clopidogrel but not aspirin reduces $P$ selectin and formation of platelet-leukocyte aggregates in patients with atherosclerosis vascular disease. Clin Pharmacol Ther 2003;73:232-41.

65. Katayama M, Handa M, Araki $Y$, Ambo H, Kawai $Y$, Watanabe $\mathrm{K}$, et al. Soluble P-selectin is present in normal circulation and its plasma level is elevated in patients with thrombotic thrombocytopenic purpura and haemolytic uraemic syndrome. $\mathrm{Br} \mathrm{J}$ Haematol 1993;84:702-10.

66. Chong BH, Murray B, Berndt MC, Dunlop LC, Brighton $\mathrm{T}$, Chesterman CN. Plasma P-selectin is increased in thrombotic consumptive platelet disorders. Blood 1994;83:1535-41.

67. Ridker PM, Buring JE, Rifai N. Soluble P-selectin and the risk of future cardiovascular events. Circulation 2001;103:491-5.

68. Mayadas TN, Johnson RC, Rayburn H, Hynes RO, Wagner DD. Leukocyte rolling and extravasation are severely compromised in P-selectin-deficient mice. Cell 1993;74:541-4.

69. Johnson RC, Chapman SM, Dong ZM, Ordovas JM, Mayadas TN, Herz J, et al. Absence of P-selectin delays fatty streak formation in mice. $J$ Clin Invest 1997;99:1037-43.

70. Weyrich AS, Ma XY, Lefer DJ, Albertine KH, Lefer AM. In vivo neutralization of $P$-selectin protects feline heart and endothelium in myocardial ischemia and reperfusion injury. J Clin Invest 1993;91:2620-9.

71. Toombs CF, DeGraaf GL, Martin JP, Geng JG, Anderson DC, Shebuski RJ. Pretreatment with a blocking antibody to P-selectin accelerates pharmacological thrombolysis in a primate model of arterial thrombosis. J Pharmacol Exp Ther 1995;275:941-9.

72. Burger PC, Wagner DD. Platelet P-selectin facilitates atherosclerotic lesion development. Blood 2003,101:2661-6.

73. Langford EJ, Parfitt A, de Belder AJ, Marrinan MT, Martin JF. A study of platelet activation during human cardiopulmonary bypass and the effect of S-nitrosoglutathione. Thromb Haemost 1997;78:1516-9.

74. Rinder CS, Bohnert J, Rinder HM, Mitchell J, Ault K, Hillman R. Platelet activation and aggregation during cardiopulmonary bypass. Anaesthesiology 1991;75: 388-93.

75. Gutensohn K, Alisch A, Krueger W, Kroeger N, Kuehnl P. Extracorporeal plateletpheresis induces the interaction of activated platelet with white blood cells. Vox Sang 2000;78:101-5. 
76. Kappelmayer J, Bernabei A, Gikakis N, Edmunds LH Jr, Colman RW. Upregulation of Mac-1 surface expression on neutrophils during stimulated extracorporeal circulation. J Lab Clin Med 1993;121:118-26.

77. Kappelmayer J, Bernabei A, Edmunds LH Jr, Edgington TS, Colman RW. Tissue factor is expressed on neutrophils during stimulated extracorporeal circulation. Circ Res 1993;72:1075-81.

78. Molenaar TJ, Twisk J, de Haas SA, Peterse N, Vogelaar $\mathrm{BJ}$, van Leeuwen $\mathrm{SH}$, et al. P-selectin as a candidate target in atherosclerosis. Biochem Pharmacol 2003; 66:859-66.

79. Ruf A, Patscheke H. Flow cytometric detection of activated platelets: comparison of determining shape change, fibrinogen binding, and P-selectin expression. Semin Thromb Hemost 1995;21:146-51.

80. Robless PA, Okonko D, Lintott P, Mansfield AO, Mikhailidis DP, Stansby GP. Increased platelet aggregation and activation in peripheral arterial disease. Eur J Vasc Endovasc Surg 2003;25:16-22.

81. Blann AD, Nadar SK, Lip GYH. The adhesion molecule P-selectin and cardiovascular disease. Eur Heart J 2003;24:2166-79.

82. Blann AD, Noteboom WM, Rosendaal FR. Increased soluble P-selectin levels following deep venous thrombosis: cause or effect? Br J Haematol 2000;108:191-3.

83. Smith A, Quarmby JW, Collins M, Lockhart SM, Burnand KG. Changes in the levels of soluble adhesion molecules and coagulation factors in patients with deep vein thrombosis. Thromb Haemost 1999;82:1593-9.

84. Myers DD Jr, Schaub R, Wrobleski SK, Londy FJ 3rd, Fex BA, Chapman AM, et al. P-selectin antagonism causes dose-dependent venous thrombosis inhibition. Thromb Haemost 2001;85:423-9.

85. Eppihimer MJ, Schaub RG. P-selectin-dependent inhibition of thrombosis during venous stasis. Arterioscler Thromb Vasc Biol 2000;20:2483-8.

86. Myers DD, Hawley AE, Farris DM, Wrobleski SK, Thanaporn P, Schaub RG, et al. P-selectin and leukocyte microparticles are associated with venous thrombogenesis. J Vasc Surg 2003;38:1075-89.

87. Falati S, Liu Q, Gross P, Merrill-Skoloff G, Chou J, Vandendries $E$, et al. Accumulation of tissue factor into developing thrombi in vivo is dependent upon microparticle $\mathrm{P}$-selectin glycoprotein ligand 1 and platelet $\mathrm{P}$ selectin. J Exp Med 2003;197:1585-98.

88. Marquardt L, Ruf A, Mansman U, Winter R, Schuler M, Buggle $F$, et al. Course of platelet activation markers after ischemic stroke. Stroke 2002;33:2570-4.

89. Yamazaki M, Uchiyama S, Iwata M. Measurement of platelet fibrinogen binding and P-selectin expression by flow cytometry in patients with cerebral infarction. Thromb Res 2001;104:197-205.

90. Minamino T, Kitakeze M, Sanada S, Asanuama H, Kurotobi $\mathrm{T}$, Koretsune $\mathrm{Y}$, et al. Increased expression of $\mathrm{P}$ selectin on platelets is a risk factor for silent cerebral infarction in patients with atrial fibrillation: role of nitric oxide. Circulation 1998;98:1721-7.

91. Cherian P, Hankey GJ, Eikelboom JW, Thom J, Baker RI, McQuillan A, et al. Endothelial and platelet activation in acute ischemic stroke and its etiological subtypes. Stroke 2003;34:2132-7.

92. Kappelmayer J, Misz M, Bereczki D, Oláh L, Fekete I, Csiba $L$, et al. Tissue factor is expressed on monocytes in young patients with stroke. Cerebrovasc Dis 1998;8:2359.

93. Amirkhosravi A, Alexander M, May K, Francis DA, Warnes $G$, Biggerstaff $J$, et al. The importance of platelets in the expression of monocyte tissue factor antigen measured by a new whole blood flow cytometric assay. Thromb Haemost 1996;75:87-95.
94. Tschoepe D. The activated megakaryocyte-platelet-system in vascular disease: focus on diabetes. Semin Thromb Hemost 1995;21:152-60.

95. Tschoepe D, Driesch E, Schwippert B, Nieuwenhuis HK, Gries FA. Exposure of adhesion molecules on activated platelets in patients with newly diagnosed IDDM is not normalized by near-normoglycemia. Diabetes 1995; 44:890-4.

96. Jilma $B$, Fasching $P$, Ruthner $C$, Rumplmayr A, Ruzicka S, Kapiotis S, et al. Elevated circulating P-selectin in insulin dependent diabetes mellitus. Thromb Haemost 1996;76:328-32

97. Kopp HP, Hopmeier P, Schernthaner G. Concentrations of circulating $P$-selectin are increased in patients with newly diagnosed insulin-dependent diabetes mellitus. Exp Clin Endocrinol Diabetes 1998;106:41-4.

98. Tschoepe D, Driesch E, Schwippert B, Lampeter EF. Activated platelets in subjects at increased risk of IDDM. DENIS Study Group. Deutsche Nikotinamid Interventionsstudie. Diabetologia 1997;40:573-7.

99. Zeiger F, Stephan S, Hoheisel G, Pfeiffer D, Ruehlmann C, Koksch M. P-selectin expression, platelet aggregates, and platelet-derived microparticle formation are increased in peripheral arterial disease. Blood Coagul Fibrinolysis 2000;11:723-8.

100. Roshan B, Tofler GH, Weinrauch LA, Gleason RE, Keough JA, Lipinska I, et al. Improved glycemic control and platelet function abnormalities in diabetic patients with microvascular disease. Metabolism 2000;49:88-91.

101. Ceriello A, Taboga C, Tonutti L, Giacomello R, Stel L, Motz E, et al. Post-meal coagulation activation in diabetes mellitus: the effect of acarbose. Diabetologia 1996;39:469-73.

102. Káplár M, Kappelmayer J, Veszprémi A, Szabó K, Udvardy M. The possible association of in vivo leukocyte-platelet heterophilic aggregate formation and the development of diabetic angiopathy. Platelets 2001;12:419-22.

103. Kim YG, Borsig L, Varki NM, Varki A. P-selectin deficiency attenuates tumor growth and metastasis. Proc Natl Acad Sci 1998;95:9325-30.

104. Kristiansen G, Denkert C, Schluns K, Dahl E, Pilarsky C, Hauptmann S. CD24 is expressed in ovarian cancer and is a new independent prognostic marker of patient survival. Am J Pathol 2002;161:1215-21.

105. Kristiansen G, Schlüns K, Yongwei Y, Denkert C, Dietel $\mathrm{M}$, Petersen I. CD24 is an independent prognostic marker of survival in nonsmall cell lung cancer patients. $\mathrm{Br}$ J Cancer 2003;88:231-6.

106. Borsig L, Wong R, Feramisco J, Nadeau DR, Varki NM, Varki A. Heparin and cancer revisited: mechanistic connections involving platelets, P-selectin, carcinoma mucins, and tumor metastasis. Proc Natl Acad Sci USA 2001;98:3352-7.

107. Nooijen PTGA, Westphal JR, Eggermont AMM, Schalkwijk C, Max R, de Waal RMW, et al. Endothelial P-selectin expression is reduced in advanced primary melanoma and melanoma metastasis. Am J Pathol 1998;152:679-82.

108. Walsh MT, Dinan TG, Condren RM, Ryan M, Kenny D. Depression is associated with an increase in the expression of the platelet adhesion receptor glycoprotein lb. Life Sci 2002:70:3155-65.

109. Malanin Al, Atar D, Callahan KP, McKenzie ME, Serebruany VL. Effect of a single dose aspirin on platelets in humans with multiple risk factors for coronary artery disease. Eur J Pharmacol 2003;462:139-43.

110. Gurbel PA, O'Connor CM, Dalesandro MR, Serebruany VL. Relation of soluble and platelet P-selectin to early outcome in patients with acute myocardial infarction after thrombolytic therapy. Am J Cardiol 2001;87:774- 
111. Moore KL, Patel KD, Bruehl RE, Fugang L, Johnson DA, Lichenstein HS, et al. P-selectin glycoprotein ligand-1 mediates rolling of human neutrophils on P-selectin. J Biol Chem 1995;128:661-71.

112. Laszik Z, Jansen PJ, Cummings RD, Tedder TF, McEver RP, Moore KL. P-selectin glycoprotein ligand-1 is broadly expressed in cells of myeloid, lymphoid, and dendritic lineage and in some nonhematopoietic cells. Blood 1996;88:3010-21.

113. Xia L, Sperandio M, Yago T, McDaniel JM, Cummings $\mathrm{RD}$, Pearson-White $\mathrm{S}$, et al. P-selectin glycoprotein ligand-1-deficient mice have impaired leukocyte tethering to E-selectin under flow. J Clin Invest 2002;109:939-50.
114. Kappelmayer J, Kiss A, Karaszi É, Veszpremi A, Jako J, Kiss C. Identification of P-selectin glycoprotein ligand1 as a useful marker in acute myeloid leukaemias. $\mathrm{Br} \mathrm{J}$ Haematol 2001;115:903-9.

115. Hrachovinova I, Cambien B, Hafezi-Moghadam A, Kappelmayer J, Camphausen RT, Widom A, et al. Interaction of P-selectin and PSGL-1 generates microparticles that correct hemostasis in a mouse model of hemophilia A. Nature Med 2003;9:1020-5.

116. Scalia R, Hayward R, Armstead VE, Minchenko AG, Lefer AM. Effect of recombinant soluble P-selectin glycoprotein ligand-1 on leukocyte-endothelium interaction in vivo. Circ Res 1999;84:93-102.

Received January 6, 2004, accepted March 5, 2004 